\title{
Pengembangan Produk Pariwisata Melalui Penerapan Prinsip-Prinsip Ekowisata Bahari Di Pantai Labuhan Amuk, Desa Antiga, Karangasem, Bali
}

Adilah Ata Nazhima a, 1, I Nyoman Sukma Arida a, 2

1 adilah_ok@yahoo.com, 2 sukma_arida@unud.ac.id

a Program Studi S1 Destinasi Pariwisata, Fakultas Pariwisata,Universitas Udayana, Jl. Dr. R. Goris, Denpasar, Bali 80232 Indonesia

\section{Abstract}

Background in this research begins with the existence of two kinds of tourism that is mass tourism and Alternative tourism, where in Alternative tourism there is one kind of tourism that is Ecotourism. Marine Tourism is one form of ecotourism. Labuan Amuk Beach has great natural potential to be developed. Lots of activities that can be done at Labuan Amuk Beach such as snorkeling and fishing. The purpose of this research is to know the existing condition of Labuan Amuk Beach, to develop product activity through its own natural potential, to identify product development opportunities, and to describe marine eco-tourism principles in Labuan Amuk Beach.

Data collection in this research is done by observation, interview, and documentation. The method used in this research is qualitative method and the collected data is analyzed descriptively qualitative. The result obtained in this research is the existing condition of Labuan Amuk Beach which consists of attraction, accessbilites, amenities, and anciliary. While the potential is in Labuan Amuk Beach is the potential of nature and get what are the opportunities of product development and know the explanation of the principles of marine ecotourism at Labuan Amuk Beach

Some suggestions that should be considered in this research are improvements to the role of government as facilitators and local communities as participants. In addition, the need for cooperation between stakeholders to synergize with each other to develop tourism in Labuan Amuk Beach.

Keyword : Development, Potential, Product, Marine Ecotourism

\section{PENDAHULUAN}

Dapat diketahui bahwa pariwisata di Indonesia saat ini sedang berkembang. Hal ini membuat para Stakeholder pariwisata ikut serta di dalam pembangunan pariwisata di Indonesia. Kemudian, Indonesia sendiri memiliki banyak potensi dalam mengembangkan pariwisata baik itu berbasis alam, budaya serta buatan. Dalam berkembangnya industri kepariwisataan saat ini membuat stakeholder terus meningkatkan dan bergerak dalam pembangunan pariwisata untuk meningkatkan kualitas dan kuantitas pariwisata serta jumlah wisatawan nusantara maupun mancanegara. Jumlah kunjungan wisatawan dan daya beli juga terus meningkat apabila komponen produk pariwisata sudah berkualitas sehingga wisatawan mendapat keuntungan dan kepuasan di daerah tujuan wisata yang mereka kunjungi.

Menurut Pendit (2002) Ada 2 (dua) macam jenis pariwisata, yaitu mass tourism atau biasa dikenal dengan pariwisata massal dan alternative tourism yang biasa dikenal dengan pariwisata alternativ. Salah satu bentuk dari pariwisata alternatif yaitu ekowisata. Menurut Arida (2010), ekowisata merupakan sebuah produk pariwisata yang memberikan penghormatan terhadap kebudayaan masyarakat lokal, tidak merusak lingkungan, serta pengembangan dalam skala kecil. Wisata Bahari merupakan salah satu jenis ekowisata dimana wisata ini memanfaatkan wilayah bahari secara langsung maupun tidak langsung. Aktivitas yang biasa dilakukan adalah Snorkeling, memancing ataupun sekedar melihat keindahan alam yang ada.

Di Bali terdapat pantai-pantai yang memiliki keindahan alam hayati dan layak untuk dikunjungi, baik berupa pantai pasir putih maupun pantai pasir hitam. Salah satu pantai yang sedang berkembang di Bali adalah pantai Labuhan Amuk. Pantai ini berlokasi di Desa Antiga, Karangasem, Bali. Pantai ini belum banyak diketahui oleh wisatawan karena aksesnya sendiri jauh dari kota. Padahal pantai ini memiliki potensi untuk terus dikembangkan.

Banyak produk wisata yang hanya menargetkan jumlah atau tingkat kepuasan wisatawan tanpa memperhatikan alam lingkungan di sekitarnya. Salah satunya pantai Labuhan Amuk yang aktivitasnya masih hanya sekedar untuk bersenang- 
senang dan kurangnya kebersihan terhadap alam dan lingkungan di pantai ini. Untuk menyikapi keadaan dan kondisi tersebut maka harus diadakannya pengembangan produk pariwisata yang berlandaskan dengan ekowisata bahari agar nantinya bisa tercipta aktivitas yang berorientasi pada nilai-nilai pelestarian alam. Aktivitas yang nantinya diciptakan juga diharapkan sesuai dengan penerapan-penerapan ekowisata bahari yang ada, seperti masyarakat lokal yang ikut berpartisipasi dalam pengembangan pariwisata, bernilai dan bermanfaat bagi wisatawan. Untuk itu peneliti ingin melakukan penelitian terkait dengan pengembangan produk pariwisata melalui penerapan-penerapan ekowisata bahari di pantai Labuhan Amuk, Karangasem.

Berdasarkan latar belakang diatas, maka rumusan masalah dalam penelitian ini yaitu bagaimana kondisi eksisting ekowisata bahari di pantai Labuhan Amuk, Karangasem, peluang pengembangan produk dan prinsip-prinsip ekowisata bahari di pantai Labuhan Amuk, Karangasem.

\section{TINJAUAN PUSTAKA}

Peneltian ini mengunakan beberapa konsep diantaranya:

1. Konsep Daya tarik wisata menurut Undang-Undang Republik Indonesia No.10 Tahun 2009 adalah sesuatu yang memiliki keunikan, keindahan dan nilai di suatu daerah.

2. Konsep Komponen Produk Pariwisata menurut Suwena (2010) adalah komponen untuk memenuhi kebutuhan dan pelayanan di suatu daya tarik wisata.

3. Konsep Potensi wisata menurut Yoeti (1996) adalah segala daya tarik yang dimiliki oleh suatu wilayah, baik berupa alam, budaya serta buatan.

4. Konsep Pengembangan Produk Baru menurut Yoeti (1999) adalah usaha yang dilakukan secara sadar dan berencana untuk memperbaiki produk yg sedang berjalan atau menambah jenis produk yang akan dihasilkan dan di pasarkan.
5. Konsep Ekowisata menurut The International Ecotourism Society dalam Arida (2002) adalah suatu bentuk perjalanan wisata yang bertanggung jawab ke kawasan konservasi.

6. Konsep Ekowisata Bahari menurut Nurisyah dalam Langga (2010) adalah jenis wisata yang memanfaatkan wilayah bahari secara langsung maupun tidak langsung.

\section{METODE}

Lokasi penelitian ini terletak di pantai Labuan Amuk, Desa Antiga, Kecamatan Manggis, Kabupaten Karangasem, Bali. Adapun ruang lingkup dalam penelitian ini yaitu:

1. Kondisi eksisting diliat dari aspek komponen produk pariwisata yaitu:
a. Atraksi (attraction)
b. Aksesbilitas (Accesbilities)
c. Fasilitas (Amenities)
d. OrganisasiKepariwisataan (Anciliary)

2. Peluang untuk menghasilkan produk baru yang harus diperhatikan, yaitu:

a. Perkembangan potensial dari pasar produk baru yang akan diproduksi

b. Fasilitas keuangan

c. Produk baru tidak akan merusak produk yang telah ada dan merugikan secara keseluruhan

Adapun prinsip-prinsip ekowisata bahari yang harus diterapkan dalam membuat suatu produk baru, yaitu:
a. Mempertahankan kelestarian dan keindahan lingkungan (alam)
b. Meningkatkankesejahteraan masyarakat di sekitar kawasan.
c. Menjamin kepuasan wisatawan.

Jenis data yang digunakan dalam penelitian ini menggunakan data kualitatif menurut Moleong (2012). Data kualitatif diantaranya, data gambaran umum, kondisi geografis Desa Antiga, kondisi eksisting di pantai Labuan Amuk. Data kuantitatif dalam 
penelitian ini adalah jumlah kunjungan wisatawan dan jumlah penduduk di kawasan pantai Labuan Amuk. Data primer menurut Bungin (2013) dalam penelitian ini adalah data berupa observasi, wawancara mendalam dengan pihak informan yang terkait.

Teknik pengumpulan data dalam penelitian ini menggunakan observasi menurut Bungin dalam Gunawan (2015). Kemudian wawancara menurut kartono dalam Gunawan (2015) dan dokumentasi menurut Sugiyono (2012). Untuk teknik penentuan informan dilakukan dengan menggunakan prosedur purposif menurut Bungin (2007) dimana menentukan informan berdasarkan kriteria tertentu sesuai dengan fokus pada penelitian. Teknik analisis data dalam penelitian ini menggunakan teknik deskriptif kualitatif menurut Moleong (2012).

\section{HASIL DAN PEMBAHASAN}

Pantai Labuan Amuk terletak di Desa Antiga, kecamatan Manggis, Kabupaten Karangasem. Dimana Desa Antiga ini merupakan daerah landai dengan curah hujan yang relatif rendah, dengan batas wilayah administratif sebagai berikut:
a. Sebelah utara : Kecamatan Selat
b. Sebelah timur : Desa Ulakan
c. SebelahSelatan: Desa Antiga Kelod
d. Sebelah Barat : Desa Gegelang

\subsection{Pariwisata di Pantai Labuan Amuk}

Salah satu pantai indah yang tersembunyi di Bali bagian timur dimana masih banyak wisatawan yang tidak mengetahui keberadaan dan letak pantai ini. Salah satu penyebab wisatawan tidak mengetahui lokasi ini karena keberadaan pantai Labuan Amuk Bali kurang terjamah dan masih kurannya promosi dari pihak pengelola. Tapi, dengan adanya potensi bahari yang luar biasa seperti coral, biota lautnya serta laut ini juga memiliki spesies karang jepun satu-satunya di karangasem dan di dunia tidak ada. Dimana karang endemik ini sangat dirahasiakan keberadaannya dan tidak terekspos. Selain itu, para nelayan juga sudah banyak yang mengetahui keberadaan pantai ini, mereka biasanya datang dari berbagai daerah di Bali untuk sekedar memancing. Dengan seiringnya waktu, pantai ini sudah mulai banyak dikenal, ada beberapa tour operator yang menawarkan produknya kepada wisatawan seperti aktivitas berupa snorkeling, diving, bahkan juga ada aktivitas wisata kapal selam. Tidak hanya itu, wisatawan juga bisa menikmati keindahan pantai dan fasilitasnya lainnya.

\subsection{Kondisi Eksisting di Pantai Labuan Amuk}

Kondisi eksisting di pantai Labuan Amuk dilihat dari aspek 4A yaitu (attraction, Accesbilities, Amenities, Anciliary Services)

\section{Atraksi (Attracion)}

Terdapat beberapa aktivitas bahari yang bisa dilakukan dan memang sudah berkembang disini, dan semua aktivitas itu bisa dilakukan oleh wisatawan yang datang ke pantai ini. Atraksi yang telah berjalan pada umumnya dikelola oleh 3 (tiga) pemilik seperti investor yaitu Odyysey Marine, kelompok nelayan dan travel swadaya yang pemiliknya berasal dari masyarakat lokal. Adapun atraksi tersebut meliputi kegiatan Snorkeling di laut labuan Amuk, memancing yang sangat digemari oleh masyarakat lokal tapi wisatawan sekarang bisa mencoba aktivitas tersebut. Kemudian ada kegiatan Sea Walker, dimana wisatawan diajak untuk menikmati pemandangan bawah laut dengan menggunakan alat khusus dan diikuti oleh pemandu yang sudah profesional. Setelah itu, ada juga Scuba Diving kegiatan ini dikhususkan bagi wisatawan yang sudah mempunyai lisensi diving. Kegiatan lainnya adalah watersport dan siapa saja bisa melakukannya.

\section{Aksesbilitas (Accesbilities)}

Dalam pariwisata akasesbilitas sangat penting dan mempengaruhi minat wisatawan untuk datang ke suatu daya tarik wisata yang diminati. Biasanya aksesbilitas ini dapat diukur dengan berapa jarak waktu yang ditempuh, keadaan jalan, dan 
transportasi apa yang dapat digunakan. Transportasi yang dapat digunakan berupa kendaraan roda dua dan empat. Untuk keadaan jalan terbilang masih harus diperbaiki mengingat tingkat kunjungan wisatawan yang semakin banyak. Untuk jarak dari Denpasar ke Labuan Amuk juga terbilang jauh dan diusahakan wisatawan yang ingin kesini, bisa datang lebih pagi agar bisa menikmati aktivitas yang diinginkan secara nyaman.

\section{Sarana dan Prasarana Kegiatan Wisata (Amenities)}

Melihat dari adanya kegiatan yang bisa dilakukan di pantai Labuan Amuk membuat pihak pengelola harus memberikan fasilitas berupa sarana dan prasarana. Fasilitas ini merupakan fasilitas yang dibutuhkan wisatawan untuk mendukung kegiatan yang dilakukan di kawasan wisata tersebut. Pelayanan fasilitas umum di pantai Labuan Amuk terbilang cukup lengkap tapi masih harus tetap dikelola dengan baik dan terus dikembangkan agar kedepannya wisatawan merasa nyaman ketika datang kesini. Adapun fasilitas yang sudah ada dan berkembang di pantai Labuan Amuk adalah loket karcis, tempat parkir, toilet umum, tempat informasi, rumah makan dan warung, Spa, perahu tradisioanal, tempat bersantai dan masih banyak lagi.

\section{Organisasi kepariwisataan (Anciliary)}

Pengelolaan di Pantai Labuan Amuk diawali dengan adanya organisasi kelompok sadar wisata (POKDARWIS) yang dulu sempat menjadi pengelola dan organisasi, tapi sekarang organisasi ini tidak aktif lagi. Kemudian pada tahun 2011 dinas pariwisata Karangasem memberiikan bantuan terhadap masyarakat lokal yang ada di desa Antiga berupa alat-alat Snorkeling untuk menunjang kegiatan pariwisata. Kemudian kepala desa Antiga sendiri juga merencanakan dalam peningkatan pariwisata dan bekerjasama dengan masyarakat lokal di pantai labuan Amuk dan membentuk suatu organisasi yang bernama Tirta bahari. Namun tidak lama kemudian organisasi ini juga tidak berperan aktif dalam mengembangkan pariwisata di sini. Kemudia setelah seiringnya waktu, masyarakat khususnya para nelayan membentuk suatu organisasi berupa Tirta Segara, Kelompok Segara Madu, dan kelolompok Bendega taman Jepun yang masih aktif sampai sekarang untuk mengelola wisata bahari yang ada di pantai Labuan Amuk. Mereka berperan dan mendukung satu sama lain dalam mengembangkan pariwisata di sini, dinas pariwisata Karangasem juga sudah mulai terbuka dan ikut berperan aktif dalam membantu pariwisata di pantai Labuan Amuk.

\subsection{Peluang Pengembangan Produk baru dan Prinsip-Prinsip Ekowisata Bahari}

\subsubsection{Peluang Pengembangan Produk Baru}

Dalam rencana membuat dan mengembangkan suatu produk baru yang akan dijadikan sebagai aktivitas bahari sudah seharusnya melihat apa saja peluang yang harus diterapkan agar rencana tersebut berjalan dengan baik dan sesuati dengan tujuan yang diharapkan. Adapun peluang-peluang pengembangan produk baru, yaitu:

1. Perkembangan potensial Pengembangan Produk Baru

Untuk menentukan produk aktivitas baru dibutuhkan ide yang sangat potensial untuk dikembangkan dan diproduksi. Setelah melakukan observasi dan wawancara terhadap pengelola di pantai ini mengenai potensi yang ada di pantai Labuan Amuk, oleh karena itu nantinya produk baru yang akan dibiuat berupa aktivitas trashveling dimana di dalamnya terdapat kegiatan berupa penanaman coral dan merawat coral yang sudah ditanam sebelumnya, beach clean up, sosialisasi tentang permasalahan sampai sampai snorkeling sangat berpotensi untuk dikembangkan dan diproduksi menjadi sebuah paket wisata alternative berbasis ekowisata bahari. Hal itu sangat berdampak positif, baik itu untuk lingkungan, perekonomian, maupun sosial budaya. 
2. Fasilitas keuangan cukup tersedia dana untuk mengembangkan produk baru tersebut.

Pengelola di pantai Labuan Amuk memiliki pemikiran yang cukup terbuka unttuk mengembangkan wisata khususnya produk aktivita baru yang nantinya dapat berkembang. Pengelola akan mencari dana baik itu membuat suatu proposal ataupun melalui pengumpulan uang berupa kas yang dikumpulkan setiap minggunya dari masyarakat lokal. Tujuannya adalah untuk mengembangkan pariwisata berbasis swadaya dimana masyarakat lokal yang sangat berperan aktif dan tinggi dalam mengembangkan produk tersebut. Sehingga nantinya akan tersedia keuangan yang cukup agar bisa mengembangkan produk aktivitas ekowisata bahari di pantai Labuan Amuk.

3. Produk Baru yang akan dikembangkan tidak akan merusak produk yang telah ada dan tidak akan merugikan secara keseluruhan

Pengembangan produk baru berupa aktivitas bahari tidak akan merusak atauapun merugikan produk lainnya. Perlu diketahui, pantai Labuan Amuk memiliki banyak sekali produk wisata seperti snorkeling dan lain-lain. Dengan dibuatnya paket wisata sangat diharpkan akan membawa banyak dampak yang potsitif yang diperoleh dari produk baru, dimana keuntungan tersebut pastinya akan diperoleh untuk alam, perekonomian masyarakat dan banyak lagi. Intinya produk lama dan produk baru nanti akan saling bersinergi dan tetap meningkatkan kualitas sehingga wisatawan yang datang menikmati dan mendapatkan pengalaman serta wawasan baru yang berkualitas.

\subsubsection{Prinsip-Prinsip Ekowisata Bahari}

Dalam mengantisipasi peluang pengembangan yang sudah diketahui sebelumnya, dalam ekowisata bahari juga harus menerapkan prinsip-prinsip ekowisata bahari untuk dijadikan pedomana untuk berpikir serta bertindak dalam mengembangkan produk aktivitas bahari di pantai Labuan Amuk. Adapun prinsip-prinsip tersebut, yaitu:

1. Mempertahankan kelestarian dan keindahan lingkungan (alam)

Saat ini pariwisata di pantai Labuan Amuk dikenal oleh wisatawan masih kurang terjaga kebersihannya, oleh karena itu tujuan dibuatnya produk aktivitas trashveling ini berguna untuk mempertahankan kelestarian yang ada di pesisir Pantai Labuan Amuk baik ekosistem laut, serta biota laut yang ada di Pantai Labuan Amuk. Selain itu, keindahan lingkungan alam di sekitar pantai juga nantinya akan bersih dan tidak ada lagi sampah-sampah plastik. Wisatawan akan terlibat dan berkontribusi dalam melakukan aktivitas beach clean up dimana wisatawan akan melakukan bersih-bersih sampah bersama dengan masyarakat lokal. Oleh sebab itu adanya kepedulian dari wisatawan dalam menjaga kelestarian alam dan keindahan lingkungan alam di pantai Labuan Amuk di tempat lainnya.

2. Meningkatkan kesejahteraan masyarakat di sekitar kawasan Pantai Labuan Amuk.

Dengan adanya produk ini nantinya akan berdampak baik khususnya pada perekonomian masyarakat lokal dan lingkungan tempat tinggal masyarakat yang ada di pantai Labuan Amuk. Peran masyarakat lokal disini sangat penting untuk kegiatan pariwisata misalnya guide local. Masyarakat lokal di Labuan Amuk masih banyak yang mata pencahariannya sebagai nelayan dan pedagang. Oleh karena itu, dengan adanya produk ini diharapkan bisa menambah peluang pekerjaan dan meningkatkan kesejahteraan masyarakat lokal di Labuan Amuk.

3. Menjamin kepuasan wisatawan

Wisatawan biasanya menginginkan sesuatu aktiitas yang belum pernah mereka lakukan sebelumnya. Dibuatnya aktivitas ekowisata bahari ini bisa menjadi alternative wisatawan untuk melakukan aktivitas yang tidak biasa dan belum pernah dilakukan sebelumnya. Aktivitas ini sangat menjamin tingkat kepuasan wisatawan meningkat karena paket produk yang 
ditawarkan serta sangat menarik untuk dilakukan. Wisatawan juga nanti akan menilai keiatan ini sangat bagus untuk dilakukan karena melibatkan alam, melibatkan masyarakat lokal, dan adanya kepedulian dalam diri dari wisatawan tersebut untuk menjaga kelestarian lingkungan alam sekitar. Jadi, pihak pengelola sangat menjamin wisatawan akan sangat puas bila produk aktivitas ini dibuat nantinya dan bisa dikembangkan lebih lanjut.

\section{SIMPULAN DAN SARAN}

\subsection{Simpulan}

Dilihat dari kondisi eksisting pantai labuan amuk terdiri dari atraksi, aksesbilitas, fasilitas, serta organisasi kepariwisataan. Sleian itu dalam pengembangan produk ekowisata bahari, terdapat peluang penembangan serta penerapan prinsip-prinsip ekowisata bahari yang harus diperhatikan. Adapun peluang pengembangan produk ekowisata bahari meliputi perkembangan potensial dari produk baru yang akan diproduksi, fasilitas keuangan, dan produk baru yang akan dikembangkan tidak akan merusak produk yan telah ada dan tidak merugikan secara keseluruhan.

\subsection{Saran}

Peran dari pengusaha atau Investor untuk selalu bekerjasama dalam mengembangkan pariwisata di pantai Labuan Amuk tanpa adanya ketidakpedulian kepada masyarakat lokal yang ada di pantai Labuan Amuk. Serta ikut berkontribusi menjaga kelestarian alam dan lingkungan aar nantinya antara investor dan masyarakat lokal saling bersinergi satu sama lain.

\section{DAFTAR PUSTAKA}

Undang-undang Republik Indonesia Nomor 10 Tahun 2009 Tentang Kepariwisataan.

Ada, Aurillia. 2016. Pengembangan Potensi Ekowisata Di Desa Liang Ndara Kabupaten Manggarai Barat. Laporan Akhir. Denpasar: Fakultas Pariwisata Universitas Udayana.

Arida, N.S. 2016. Dinamika Ekowisata Tri Ning Tri di Bali. Denpasar: Pustaka Larasan.
Bungin, Burhan. 2007. Penelitian Kualitatif. Jakarta: Kencana.

Gunawan, Imam. 2015. Metode Penelitian Kualitatif. Jakarta: Bumi Aksara.

Ibrahim. M.A. 2015. Metodologi Penelitian Kualitatif Panduan Penelitian Beserta Contoh Proposal Kualitatif. Bandung: Alfabeta.

Langga, Adi Nexon Tomyan. 2010. Kajian Sumberdaya Terumbu Karang untuk Pengembangan Ekowisata Bahari di Perairan Kecamatan Semau, Kabupaten Kupang, Provinsi Nusa Tenggara Timur. Jurnal Lanskap Indonesia Vol. 4 No.1

Moleong. 2012. Metodologi Penelitian Kualitatif. Bandung: PT Remaja Rosdakarya.

Mulia, Dedi. 2004. Alternatif pengembangan gugusan Pulau Pari Kepulauan Seribu sebagai Obyek Ekowisata Bahari di DKI Jakarta. Diss. Jurnal Manifakstur Vol. 2 No. 3

Pragawati, Bunga. 2009. Pengelolaan Sumberdaya Pesisir Untuk Pengembangan Ekowisata Bahari Di Pantai Binangun, Kabupaten Rembang, Jawa Tengah. Jurnal Kelautan Vol. 2 No. 6

Sugiyono. 2012. Metode Penelitian Kuantitatif Kualitatif dan $R \& D$. Bandung: Alfabet.

Suwena, I.K. 2010. Pengetahuan Dasar Ilmu Pariwisata. Denpasar: Udayana University Press.

Yoeti, O.A. 1999. Perencanaan\&Pengembangan Pariwisata. Jakarta: Pradnya Paramita. 